\title{
The Path of a Saint: Buddhaghosa's Argument for Sustainable Development
}

\author{
Ścieżka świętego: \\ argument Buddaghosy na rzecz zrównoważonego rozwoju
}

\author{
Gyan Prakash
}

\author{
Department of Humanities and Social Sciences, IIT(ISM) Dhanbad, India \\ E-mail:gyan@iitism.ac.in
}

\begin{abstract}
A philosophical investigation of sustainable development has much to contribute to the study of philosophy of religion because religion has significant effect on human behavior. In Indian philosophy, to be precise, early Buddhist Philosophy argues for individual suffering and it's solution. Notwithstanding, there is an argument that Buddhist philosophy does not motivate an individual to make efforts for sustainable development or preservation of natural resources. Therefore, one cannot contemplate the problem of sustainable development under early Buddhist philosophical framework. To refute this view, I have attempted to analyze Buddhaghosa's notion of virtue. In this paper, I have argued that, there is a significant implication of the study of virtue for the area of sustainable development. This, consequentially, imparts significance to the balanced consumption of natural resources and balanced consumption of natural resources is vital for sustainable development.
\end{abstract}

Key words: early Buddhism, sustainable development, religion, Buddhaghosa, natural resources

\section{Streszczenie}

Filozoficzne badanie zrównoważonego rozwoju ma duży wkład w studiowanie filozofii religii, ponieważ religia ma znaczący wpływ na ludzkie zachowanie. Mówiąc precyzyjniej, w filozofii indyjskiej wczesna filozofia buddyjska opowiada się za indywidualnym cierpieniem i rozwiązaniem. Niezależnie od tego istnieje argument, że filozofia buddyjska nie motywuje jednostki do podejmowania wysiłków na rzecz zrównoważonego rozwoju lub zachowania zasobów naturalnych. Dlatego nie można kontemplować problemu zrównoważonego rozwoju we wczesnych buddyjskich ramach filozoficznych. Aby obalić ten pogląd, próbowałem przeanalizować pojęcie cnoty Buddhaghosy. W tym artykule argumentowałem, że badanie cnoty ma znaczący wpływ wspieranie zrównoważonego rozwoju. W konsekwencji nadaje to znaczenie zrównoważonemu zużyciu zasobów naturalnych, a zrównoważone zużycie zasobów naturalnych ma zasadnicze znaczenie dla zrównoważonego rozwoju.

Słowa kluczowe: wczesny Buddyzm, zrównoważony rozwój, religia, Buddaghosa, zasoby naturalne

\section{Introduction}

There is an established link between environment, society and economics. For instance, agricultural policies can recommend the overuse of chemical fertilizers and that can be the cause of water pollution and land degradation (Baker, 2006, p.19). My intention in making a reference to the Baker argument that elucidates upon the link between the environment, economy and society is to show that our environment is deeply affected by our thoughts, which manifest in action and become habits. Thinking and working towards sustainable development is not possible single handedly. It is our collective responsibility. Further, when we talk about collective action then, religion always takes a dominant position because philosophy of religion has a deep influence on human beings. Notwithstanding, Indian Buddhist philosophy has been looked upon as one that provides the solution of individual suffering only. Here, individual suffering refers to suffering which is caused by individual's set of desires and inclinations (Prakash, 
2018). Therefore, it is said that, early Buddhist philosophy does not talk about the natural resources or sustainable development. To refute this interpretation, I have delved into an authoritative early Buddhist text, Visuddhimagga, written by Buddhaghosa in the $6^{\text {th }}$ century.

The Buddhist text, Visuddhimagga, concerns itself with the manner in which one can purify his mind and end suffering. It is true that there is no direct reference to natural resources, in the text, because at that time the society had not deliberated upon the degrading state of natural resources and it's significance for man. Notwithstanding, in this paper, I have argued that if one follows the recommended path of Buddhaghosa then, there will be no exploitation of natural resources. The paper focusses upon the first chapter of Visuddhimagga. The chapter, titled Sila (virtue), deals with the concept of virtue and the nature of virtue. In the paper, I have argued as to how Buddhaghosa's recommended path of a saint is also an equally significant step for sustainable development.

\section{The Path of a Saint: Buddhaghosa's perspective}

In the first chapter of Visuddhimagga, Buddhaghosa has explained the nature of virtue. He defines virtue by saying that virtue can be understood as a function which is accomplished by discontinuing the misconduct in terms of action (Nanamoli, 1956, p. 12). Therefore, for Buddhaghosa, the manifestation of virtue can be seen in terms of bodily purity, verbal purity and mental purity. For early Buddhists, virtue can purify not only the physical, but verbal and mental also. There are mainly four types of virtues mentioned in the text. These are virtue as volition, virtue as consciousness-concomitant, virtue as restraint and, finally, virtue as non-transgression (Nanamoli, 1956, p. 10). I will discuss all the four types of virtues in this section and, in next section, I will argue that it will be easy to achieve the goal of sustainable development if one follows Buddhaghosa's mentioned path of a saint.

In the first argument, Buddhaghosa has argued that virtue is a volition. In early Buddhist philosophy, cetana is often translated as volition or intention (Keown, 1992, p. 220). Buddhaghosa writes that, virtue as volition refers to the volition present in one who follows the five precepts. Before going to the explanation of the five precepts, let us discuss the notion of volition in early Buddhist philosophy. In early Buddhism, intention of action plays an important role. The original Sanskrit term karma literally means action and, according to the early Buddhist theory of action, one will have to face the consequences of one's actions. Further, we need to understand that, sometimes action does not produce immediate effect. In the popular Buddhist understanding, the law of kamma is an option wherein an individual acts in such a way as he wishes, to shape his future.
In other words, the fruits of our actions contribute key dimensions to our future life. Thus, we are responsible for our actions and the future world. Again, for Buddhism, our personality is the effect of our set of past desires and inclinations. Early Buddhists argue that our actions shape not only our future but also our personality. Therefore, one has to be very careful while performing any action and, for all actions, intention is very important because action cannot be judged merely by itself. Intention plays a significant role in it. Buddhaghosa, with reference to the first virtue, writes that the intention of performing the following five Buddhist moral precepts is important. These five noble precepts, known as Pancasila, are - (1) abstain from killing, (2) abstain from stealing, (3) abstain from telling lies, (4) abstain from living immoral life and (5) abstain from consuming intoxicants. These constitute the basic teaching of Buddha and are accepted by all schools of Buddhist philosophy. Among the five noble precepts, the first is very significant for the problem of this paper. Further, the other four precepts are essential for self-purification so that one can restraint himself from any immoral act in any kind of mental state. Therefore, I will focus upon the first precept only in my attempt to analyse Buddhist contribution towards sustainable development. The first precept, that is non-violence or non-killing, is known as ahimsa. It is a prominent and common concept in all Indian religions. It means positive love in the form of compassion and friendship towards all beings - in thought, word and deed. In Buddhism, killing in any form is prohibited. Life is dear to all creatures. All living beings, irrespective of age, sex, size, from the time of their conception in the mother's womb are under this precept's purview. This percept wards off the scope for recent ethical issues - not only capital punishment, but also euthanasia and abortion. It is significant to note that these five moral precepts are prescribed for both the householders and renunciates.

The second virtue is virtue as consciousness concomitant. Here, consciousness concomitant is mental state or cetasika. According to early Buddhism, cetasika has four main characteristic properties. Firstly, it arises together with consciousness. Secondly, it perishes together with consciousness. Thirdly, it takes the same object as consciousness and, finally, it shares a common physical base with consciousness. Consciousness and mental properties function in the same manner. In Buddhism, there are different kinds of consciousness and mental states. Buddhaghosa writes that virtue as consciousness concomitant expresses itself as self-discipline in one who follows the five precepts. Therefore, this virtue is a mental state with the essential characteristic of non-covetousness.

Third virtue is virtue as restraint and it should be elucidated upon as restraint exercised in five different ways: restraint based upon the rules of community 
(Patimokkha), restraint due to mindfulness, restraint due to knowledge, restraint due to patience and restraint due to energy (Nanamoli, 1956, p. 11). Let us, herein, understand the notion of patimokkha. Uposatha is the term used to describe the day of full fasting as observed on the days of new moon, waxing moon, full moon and waning half-moon. In these days, everyone gathers in a meeting hall and recites the patimokkha. In this special meeting, a senior monk solemnizes the ceremony and all monks confess their sins. The process of this ceremony is as follows - the senior monk asks the other monks to accept or declare the offence which they have committed or keep silence (Sebastian, 2004). Basically, this ritual gives an opportunity to accept and rectify mistakes. It is called patimokkha because it is the virtue of training in precepts: for it frees the monk or nun who protects it, guards it and sets him/her free from the pains of the states of loss etc. (Nanamoli, 1956, p. 19). My main intention in elucidating upon the concept of patimokkha is to show that Buddhism emphasized purity - purity of thought, purity of action and Uposatha ceremony is all about purity. It is significant to note that Buddhism believes in correction and transformation and Uposatha ceremony is one of the strongest examples of this aspect. Buddhism proposes that a person possesses great deal of freedom and he/she can act accordingly. Notwithstanding, if he/she commits any mistake then, he/she should confess it and try to reform himself/herself.

The last virtue is known as virtue as non-transgression. This virtue suggests that one should practice non-transgression, through the medium of body or speech, of the precepts of virtue that have been undertaken for purification. However, one may ask about the benefit or utility of practicing virtue. Buddha, according to the Visuddhimagga text, responded that virtue leads to non-remorse and this leads to the complete extinction (Nanamoli, 1956, p. 12).

For Buddhaghosa, discipline is the first step towards Nirvana and, therefore, one has to follow this path strictly (Nanamoli, 1956, p. 16).

\section{Discipline- Restraint- Non-remorse- Gladdening- Happiness- Tranquility- Bliss- Concentration- Correct Knowledge- Dispassion- Fading Away of Greed- Deliverance- Knowledge and Vision of Deliverance- Complete extinction}

Buddhaghosa has argued that everyone in this world is equal and true path of a saint necessitates looking upon everyone equally. He mentions the story of an old monk in his book. Once upon a time, an elderly man was on his way, from one place to the other, begging for alms. At the same time, a woman who had a fight with her husband was going to see her relative, on the same path. She saw the monk and laughed loudly. After some time, her husband approached this elderly monk asking about his wife's whereabouts. The monk said that he had no idea whether it was a man or a woman, but that he had seen a couple of bones going towards the other side (Nanamoli, 1956, p. 23-24). This story helps us understand that, according to early Buddhism, everyone is equal and diversity is found only at the apparent level. Reality is different at the apparent and ultimate level. Therefore, everyone should follow the path of a saint. Buddhaghosa's ethical teaching has significant implications for the concept of sustainable development. In the next section of this paper, I will argue the same point.

\section{Buddhaghosa's Argument and Natural Re- sources}

In this section, I will argue as to how Buddhaghosa's notion of virtue supports sustainable development. Buddhaghosa's idea of the first virtue exhibits that volition or intention is important for the observation of the five precepts. As we have discussed above, Buddhists have used the word intention for volition. Western philosopher, Gilbert Ryle, had a similar kind of conception of agent and action. According to Ryle, if one acts intentionally then his action is voluntary (Ryle, 1963, p. 68). In order to explain this further, let us take an instance of a boy who arrives late at school. After the investigation of his school teacher, it turns out that the boy left home at the usual time, did not get delayed on his way to the bus stop and caught the usual bus. However, the bus broke down and could not complete the journey. The boy tried his best to reach the school on time. There was nothing else that he could have done for remedying the effect of the breakdown of his vehicle. Even though he ran as fast as he could, he could not reach the school on time. In this example, the boy's late appearance was not the result of his failure to do what he was capable of. In fact, he was prevented by the situation which was not under his control. Ryle writes that when a person does something voluntarily and tries to finish it, then his action certainly reflects some quality of the mind (Ryle, 1963, p. 72). Ryle points out that the distinction between voluntary and involuntary applies to both the mental and physical. For instance, if something just reminds me of my sister, then I think of her involuntarily. Alternatively, I can start to think about her deliberately. In the latter case, a volition has occurred because it is a voluntary mental event. My main intention in discussing Ryle's notion of mind is to put forth that volition does not refer to a passing or weak desire to perform an action. Volition refers to a strong desire or intention to perform an action. As Ryle has illustrated, one has to act out his desired action as far as possible and that is called strong intention. Therefore, when Buddhaghosa refers to the first virtue as volition, it refers to a strong desire or intention to follow the five precepts. 
Let us understand as to how these precepts are significant for sustainable development. Among the five, the first precept is very significant for the purposes of our paper. It asks one to abstain from killing. It argues that a person, who wants to achieve the ultimate truth, has to abstain himself from killing any sentient being. Early Buddhist philosophy has a very different attitude towards the notion of sentient beings. Many Buddhist scholars have argued that sentient being refers to living beings only. Visuddhimagga has also said that the first precept is all about restrain from killing living beings. However, there is an argument that, in many Buddhist traditions, grass and trees are also looked upon as sentient being (Prakash, 2018, p. 219). In this paper, I will not elaborate upon the limitation of the notion of sentient being in Buddhist philosophy. Also, when I use the term sentient being, I will refer to living beings only and not grass and trees. This is so because I want to demonstrate that, even if we exclude grass and trees from the category of sentient beings, we can argue for the preservation of natural resources, if we follow the path of a saint or make efforts for the cessation of our own suffering. According to early Buddhism, intention is significant for any action. For instance, one can kill an ant without intention. Thus, if an ant died because $\mathrm{X}$ unknowingly stepped upon the creature, then this action will not lead to any bad fruits. Therefore, for Buddha, in order to illustrate the act of killing, one needs to show the intention to kill and the consequent death of a living being (Adam, 2006, p. 228). Adam writes that Buddhists adopted the pragmatic approach when it came to action. Notwithstanding, Buddha has maintained that one should avoid killing or harming any living being to the greatest degree possible (Adam, 2006, p. 228). Now let us understand the act of killing. There are two ways in which one can kill a living being. Firstly, by means of physical attack or weapons and, secondly, by finishing all the resources of particular living beings. For instance, if someone endeavors to finish or overuse the natural resources, he is working towards finishing the lives of many other living animals and creatures, who are dependent on these resources. For instance, deforestation can cost many wild animals, millions of insects and other living beings their lives. According to the Buddhist notion of non-violence, if an individual is using the natural resources for one's own survival, then his act is nonviolent. However, if one is exploiting the natural resource with the knowledge that his act would take the lives of many other creatures, then his act is violent. All of us are aware of the fact that, slowly, we are exhausting our natural resources. Also, if we fail to preserve our natural resources then, not only will we kill many living creatures but also we will not have anything left for the future generations. Therefore, if a person intends to follow the first precept, he needs to circumvent both types of killings and renounce deforestation, which will result in saving the natural resources. Nelson writes that Buddha abjured moral indifference to the fate of other creatures (Nelson 206, p. 2009).

The second virtue, virtue as consciousness concomitant, argues for the preservation of natural resources for the benefit of both other creatures and future generations. As discussed earlier, consciousness concomitant or mental states play a significant role in action. Appearance of mental states is always dependent on the desire and inclination of the person. According to Buddhism, purposive activity is behavior with a mental cause. For instance, suppose I have (form) the intention to strike someone. It means that my mind is in a certain state and my action is merely the effect of this mental state. Early Buddhism contends that mental state causes not only a particular kind of behaviour but also other mental states. Guenther writes that, according to early Buddhism, one performs an action mainly due to passionate desire. Action and emotion or mental state play a crucial role in human suffering. The selection of an object is completely dependent upon individual temperament (Nanamoli, 1956, p. 453). Guenther writes that action and the emotion are the main reasons for our existence in this world and emotions also influence one's future existence (Guenther, 1991, p. 9). Here, it is clear that mental states play a significant role in action. Therefore, if one possesses ethically wrong desires, he will indulge in immoral acts. Here, by referring to the Buddhist notion of consciousness concomitant, I wish to demonstrate the essential relationship between mental state and action. According to the second virtue, if an individual puts a lot of effort in the practice of the first virtue, then (eventually) the individual can control his mental states, which arise with his mind. In this manner, the individual can, to a great degree, avoid killing or harming others.

The third virtue is virtue as restraint. This virtue is basically prescribed for monks and nuns, but it holds significance for common man or family persons also. In this regard, Buddhaghosa has given importance to both accepting the mistake and rectifying it or vowing not to repeat the same. Buddhist philosophy believes in rectification of errors. Therefore, even if a person has committed a crime or mistake, he is asked to acknowledge it and vow not to repeat it. The application of this virtue, against the backdrop of this paper, lies in firstly realizing that we have been exploiting the natural resources and are in a dangerous situation. Secondly, we need to analyse the situation and correct our error immediately. We should work towards sustainable development and stop exploitation of natural resources.

The last virtue advocates that one should demonstrate a strong determination towards the above mentioned five precepts. Buddhaghosa has argued that one should abstain from misconduct of both action and speech. This virtue shows that our determination regarding the five precepts should be robust. The 
path of the saint, or an individual who desires to work towards the complete cessation of suffering from his life, lies in the above suggested direction of virtues. In this paper, my main contention is that, if one follows the path of the saint he can contribute towards sustainable development. Therefore, as early Buddhist argues, the removal of suffering is significant or the only goal of our life. What we see as real, is not real in the ultimate sense. Correspondingly, we also have to make efforts for the preservation of natural resources, for the present and future generations, and this step can be taken together with working for the removal of our own suffering.

\section{Conclusion}

In this paper, I have argued that Buddhaghosa argument for the notion of virtue is very much significant for the notion of sustainable development. However, I would like to admit that there is no direct reference to natural resources in the Buddhaghosa's text Visuddhimagga and the path of the saint is recommended for an individual to break free from the cycle of birth and rebirth or suffering. Notwithstanding, I have argued that if one follows the path of a saint, which is endorsed and illustrated by Buddhaghosa, he/she will end up protecting our natural resources and offering significant contribution towards sustainable development.

\section{References}

1. ADAM M. T., 2006, Nonviolence and Emptiness: Buddha, Gandhi and the 'Essence of Religion', in: ARC, (34), p. 225-238.

2. BAKER S., 2006, Sustainable Development, Routledge, Taylor \& Francis, New York.

3. DE SILVA C. L. A., 1997, A Treatise on Buddhist Philosophy of Abhidhamma, Sri Satguru Publications, Delhi.

4. GUENTHER H. V., 1991, Philosophy and Psychology in the Abhidharma, Motilal Banarsidass Publishers, Delhi.

5. KEOWN D., 1992, The Nature of Buddhist Ethics, Palgrave, New York.

6. NANAMOLI B., 1956. The Path of Purification, Singapore Buddhist Meditation Centre, Singapore.

7. NELSON E. S., 2009, Virtue and Violence in Theravada and Sri Lankan Buddhism in Buddhist Roles in Peacemaking, ed. Mun Ch., Green R.S., Blue Pine Books, Honolulu, p. 199-233.

8. PRAKASH G., 2018, Buddhist Attitude towards Sustainable Development, in: Problemy Ekorozwoju/ Problems of Sustainable Development, 13(1), p. 217 220.

9. RYLE, G., 1963, The Concept of Mind, Penguin Books, Harmondsworth.

10. SEBASTIAN, C.D. 2004, 'Confession' in Christianity and Buddhism, in: Jnanatrirtha, 4(2004), p. 48-49. 
